\title{
Does Exposure to Stereotype-Disconfirming Politicians Reduce the Effect of Stereotypes on Voting? Evidence From Seven Plagiarism Scandals in Germany
}

\author{
Michael Herrmann \\ University of Konstanz \\ Markus Tepe \\ University of Oldenburg
}

\begin{abstract}
We examine whether exposure to several salient counterexamples reduces the effect of stereotypes on voting. By taking advantage of a series of seven plagiarism scandals in Germany-a country with high regard for academic credentials where academic titles (Dr. and Prof.) get printed on ballot papers-we test whether the tendency to vote for candidates with a doctor's title decreased in the wake of the scandals. Using crosssectional and longitudinal estimators and controlling for a large range of potential confounders, we find that the electoral advantage of candidates with a doctor's title shrinks from a good half of a percentage point before the scandals down to a third after the scandals. In line with a subtyping hypothesis, the reduction is stronger for candidates from traditional middle-class parties (i.e., the parties of the politicians who were implicated in the scandals). Neither of these effects turns out to be strong enough to reach statistical significance, however. We conclude that seven negative examples in one legislative term had no noticeable effect on the tendency to select candidates based on academic titles. Our study provides a rare opportunity to test the effect of stereotype-disconfirming information on electoral behavior. Our results contribute to a literature demonstrating the resilience of stereotypes to disconfirming information. They also suggest that plagiarism affairs are unlikely to reduce electoral incentives for politicians to obtain a fake doctorate.
\end{abstract}

KEY WORDS: Dr., doctor's title, doctor's degree, doctorate, electoral success, stereotype change, subtyping

Voters often find themselves in situations where they do not know much about the candidates who are up for election. To compensate for the lack of information, voters often rely on "mental shortcuts" in forming an image of the candidates (Lau \& Sears, 1986; McDermott, 1997; Steenbergen, 2010). Such shortcuts allow them to make accurate assessments of candidates based on little information, for example, when judging candidates based on their party affiliation (Lau \& Redlawsk, 2001; Popkin, 1994). On the downside, however, reliance on mental shortcuts also makes electoral choices vulnerable to social stereotypes. ${ }^{1}$ Studies show that stereotypes about race, gender, and other attributes may affect candidate evaluation and vote choice (e.g., Holli \& Wass, 2010; Huddy \& Capelos, 2002;

\footnotetext{
${ }^{1}$ Stereotypes are expectations about social groups that are used to judge a target individual (Chaxel, 2015, p. 641).
} 
Jacobsmeier, 2015; Koch, 2002; McDermott, 1997, 2007; Olivola, Sussman, Tsetsos, Kang, \& Todorov, 2012; Pasek, Stark, Krosnick, Tompson, \& Payne, 2014). Given that stereotypes have these electoral effects, an important question is whether they can be reduced.

We take up this question by examining whether exposure to politicians who defy a stereotype reduces the stereotype's effect on voting. We ask: How much change in electoral behavior can we expect from exposing voters to politicians who disconfirm their stereotype? To address this question, we study a bias among voters in Germany: the tendency to favor candidates with academic titles (Dr. and Prof.). Academic credentials are well-respected in German society, and ballot papers display academic titles prominently on the day of the election. Previous work indicates that German voters prefer candidates who possess such titles (e.g., Schneider \& Tepe, 2011). To test whether exposure to negative counterexamples has an effect on this bias, we take advantage of a unique and unprecedented series of plagiarism scandals during which seven politicians lost their doctorate. The scandals received much attention in the German media. They involved two well-known cabinet ministers, who both resigned after losing their doctorate, the vice-president of the European Parliament, and several less well-known politicians from the Bundestag, the European Parliament, and two state parliaments. The incidents occurred throughout the second half of the 17th legislative term (2009-13). The last one, in which the minister of education lost her doctorate, took place just four months before the next election.

A large experimental literature in social psychology suggests that it is possible to reduce the influence of stereotypes by exposing subjects to counterexamples (e.g., Allport, 1979; Blair, 2002; Bless, Schwarz, Bodenhausen, \& Thiel, 2001; Bodenhausen, Schwarz, Bless, \& Wänke, 1995; HendersonKing \& Nisbett, 1996). What we do not know yet is how well these effects travel to actual elections. Our findings suggest that even a spate of highly negative examples in one legislative term is not enough to significantly alter a voting bias. Specifically, we find that candidates with academic titles (Dr. and Prof.) won significantly more votes than other candidates at both elections. Although this advantage decreases in the election following the scandals (from a good half of a percentage point down to a third of a percentage point), the reduction does not reach statistical significance. In line with the hypothesis that the scandals led to "subtyping" of candidates from traditional middle-class parties (Christian democratic and liberal parties) who possess a doctor's title, we find that those candidates lost more votes than candidates from other parties; but again, the reduction is statistically insignificant. Overall, the evidence suggests that the scandals had, at best, a small effect on the electoral performance of candidates with doctor's titles.

Our study makes three contributions. First, it provides a rare opportunity to test the effect of stereotype-disconfirming information on voting behavior in an actual election. Determining these effects is important because we cannot directly infer them from the extant experimental literature. Our results provide a point of reference for how much reduction in stereotype-based voting one can expect in such a setting. The apparent lack of an effect of the plagiarism scandals shows that stereotypes can be very resilient in electoral settings even if counterexamples are highly salient.

Second, our results tie in with the large literature on mental shortcuts in voting. This literature has shown that candidate characteristics such as race (Pasek et al., 2014), gender (Holli \& Wass, 2010), religion (McDermott, 2007), age (Marcinkiewicz, 2014), ethnicity (Fisher, Heath, Sanders, \& Sobolewska, 2015), birthplace (Tavits, 2010), place of residence (Arzheimer \& Evans, 2012), occupation (McDermott, 2005), or looks (Miller \& Lundgren, 2010; Prior, 2014; Todorov, Mandisodza, Goren, \& Hall, 2005) may affect candidate electoral success. A key factor triggering many of these effects is information provided on ballot papers (e.g., Arzheimer \& Evans, 2012; Banducci, Karp, Thrasher, \& Rallings, 2008; Buckley, Collins, \& Reidy, 2007; Giger, Holli, Lefkofridi, \& Wass, 2014; Kelley \& McAllister, 1984; McDermott, 1997; Mechtel, 2014). While Germany is currently not the only country in which academic titles are displayed on ballot papers (other examples include, for instance, Austria, Finland, Hungary, or Switzerland), the international literature has largely neglected 
titles printed on ballot papers as a source of influence on vote choices. ${ }^{2}$ Our findings suggest that removing titles from ballot papers may be the only way to mitigate their effects in elections. For instance, ballot papers in the United Kingdom do not show titles anymore, but in the past this practice has helped candidates with honorary titles (but not academic titles) win more votes (Kelley \& McAllister, 1984).

Finally, our study contributes to the literature on political scandals and their consequences. The bulk of studies in this literature investigates how voters perceive and evaluate scandalous politicians (e.g., Bhatti, Hansen, \& Olsen, 2013; Funk, 1996; Miller, 2010; Mitchell, 2014) and how scandals affect evaluations of politicians and political institutions (e.g., Bowler \& Karp, 2004; Maier, 2011; Schwarz \& Bless, 1992). Our study is different in that it looks at whether scandals affect how voters react to politicians who belong to the same social group as the scandalous politicians. Our findings add to recent results suggesting that scandals exert only modest effects on voting in subsequent elections (e.g., Basinger, 2013; Eggers, 2014; Rudolph \& Däubler, 2016; Vivyan, Wagner, \& Tarlov, 2012).

\section{Exposure to Counterexamples and Stereotype Change}

Stereotypes are not set in stone. A large literature in cognitive psychology suggests that exposure to stereotype-disconfirming individuals may reduce a stereotype's impact on subsequent judgments of other persons (e.g., Allport, 1979; Blair, 2002; Bodenhausen et al., 1995; Henderson-King \& Nisbett, 1996; Valentino, Hutchings, \& White, 2002). One mechanism behind this effect is the increased accessibility of counterexamples. Exposure to counterstereotypic individuals makes those individuals come to mind more easily in subsequent judgments, and this may override or weaken the stereotype (Dasgupta \& Greenwald, 2001, p. 808). For instance, exposure to admired African Americans and disliked White Americans can decrease automatic racial prejudice (Dasgupta \& Greenwald, 2001). Another influence of counterexamples lies in their potential to change stereotypic beliefs (Bless \& Schwarz, 1998; Bless et al., 2001; Bodenhausen et al., 1995). In forming and updating beliefs about social groups, observers frequently incorporate information from individual exemplars (Bless et al., 2001). Thus, for example, exposure to specific politicians who were involved in public scandals can change how observers think of politicians in general (Régner \& Le Floch, 2005; Schwarz \& Bless, 1992). A potential moderator in the reduction of stereotypes is the frequency of exposure. As Dasgupta and Asgari (2004) show, for instance, female college students who were exposed to more female professors during their first year of college exhibited a greater reduction in stereotypic beliefs about women's roles in society than female students at colleges that had fewer female professors. Thus, they conclude, greater exposure to stereotype-disconfirming individuals facilitates stereotype change.

Despite evidence on the malleability of stereotypes, the psychological literature also demonstrates that stereotypes tend to resist change. Observing information which conflicts with existing prior beliefs may lead to arousal and cognitive dissonance (Festinger, 1957). Attempts to reduce such dissonance often give rise to motivated reasoning whereby people selectively access, construct, and evaluate information so as to uphold their prior beliefs and attitudes (Kunda, 1990). As a result, observers presented with stereotype-disconfirming exemplars do not always revise their beliefs about the larger social group. Instead, they engage in so-called subtyping (e.g., Johnston \& Hewstone, 1992; Kunda \& Oleson, 1995; Maurer, Park, \& Rothbart, 1995; Richards \& Hewstone, 2001; Weber \& Crocker, 1983).

\footnotetext{
${ }^{2}$ Two notable exceptions are Kelley and McAllister (1984) and Jurajda and Münich (2015), who study the effect of academic titles in the 1974 U.K. general election and Czech municipal elections, respectively.
} 
Subtyping refers to the act of fencing-off deviant cases in an attempt to maintain the stereotype (Richards \& Hewstone, 2001). This weakens the stereotype's effect on subsequent judgments of members of the deviant group, while the general stereotype remains intact (Kunda \& Oleson, 1995). An important factor related to the likelihood of subtyping is the availability of additional information that allows observers to insulate the deviant cases from the stereotype. In particular, information that was irrelevant before observing the deviant cases can become the focus of later attempts to explain their deviance (Kunda \& Oleson, 1995). To rescue the stereotype, however, observers must actively construct new categories that are consistent with the observed evidence (Yzerbyt, Coull, \& Rocher, 1999). This requires greater effort the more disconfirming exemplars differ from each other. As a result, stereotype change becomes more likely when disconfirming information is dispersed across exemplars rather than concentrated within a single individual (Hewstone, Johnston, \& Aird, 1992; Hewstone, Macrae, Griffiths, Milne, \& Brown, 1994; Weber \& Crocker, 1983; Yzerbyt et al., 1999).

Taken together, the experimental literature suggests that exposure to counterexamples can reduce stereotypes and the possibility of stereotype change should increase in the frequency of deviant cases. What we do not know much about is how well these effects travel to an actual election. Can we expect voters to change their stereotypes after exposure to politicians who disconfirm them? And how many counterexamples would it take to induce such change?

Obviously, we cannot manipulate the information that voters receive about actual politicians in an election in order to test if this affects how they vote. One solution to this problem is to focus on situations in which "nature" provides the stereotype-disconfirming politicians for us. An example for this comes from a recent literature on the "Obama effect" (see, e.g., Columb \& Plant, 2011; Pasek et al., 2014; Plant et al., 2009; Schmidt \& Nosek, 2010). ${ }^{3}$ Studies in this literature examine whether the election of President Obama in 2008 led to a reduction in racial prejudice and race-based voting. The argument is that President Obama servers as a highly salient counterexample to stereotypical views of Black persons which should make it harder to maintain such views (e.g., Goldman, 2012; Hutchings, 2009). Here we take a similar approach. We also capitalize on an exogenous intervention which provides salient counterexamples for a common stereotype to test if this reduces the stereotype's effect on voting. Our approach differs in that we focus on a spate of stereotype-disconfirming politicians rather than a single one. Given what we know from the experimental literature, this should create a situation that is conducive to stereotype change.

\section{Academic Titles in German Politics and Society}

In the United States, the United Kingdom, and many other countries, only physicians carry the title "Dr." outside academia. By contrast, in Germany the doctor's title is also used in other situations. For example, it is considered polite in formal settings to address someone as "doctor" if the person holds a doctoral degree. The doctor's title also enjoys special legal status: Holders of a doctoral degree in Germany are entitled to display the Dr. on their identity card and passport. Other academic titles cannot be inscribed on passports or IDs. Given its special status, Germans are not shy to use the Dr. in various situations. For example, many use their title in official letters and some also display it on their mailboxes or in phone directories. The professor's title (formally: Prof. Dr.) is also frequently used this way. In a recent report by Transparency International on academic promotion in Germany, the situation is described as follows: "As many Germans place strong emphasis on academic titles, a

\footnotetext{
${ }^{3}$ Related examples include Puente-Diaz (2015), who exploits ambiguity about the party affiliation of two prominent Mexican politicians to study how perceived party membership of one politician affects evaluations of the other; and Régner and Le Floch (2005) as well as Schwarz and Bless (1992), who capitalize on political scandals in France and Germany to study how awareness of politicians who were implicated in the scandals affects evaluations of politicians in general. Neither of these studies considers voting in an election as a potential outcome.
} 
doctoral degree can raise one's reputation in German society. This situation has not changed much in the last 15 years" (Wolf, 2013, p. 178). This emphasis on academic degrees is further evidenced by the fact that the share of doctorate holders in the population or labor force is two to three times larger in Germany than in Australia, Canada, or the United States, according to an OECD study from 2004 (Auriol, 2007).

Given its status in German society, the Dr. is also frequently on display in politics. For instance, Chancellor Merkel's name tag at press conferences does not read "Chancellor Merkel" or "Mrs. Merkel”; it reads "Dr. Merkel." Former chancellor Helmut Kohl, who also holds a doctorate, was formally addressed as "Dr. Kohl." The same practice is applied in addressing cabinet ministers and other politicians. In fact, the Bundestag itself lists the names of all MPs including their academic titles and German state parliaments follow the same practice (see the online supporting information for examples).

Finally, academic titles are also on display in elections. In Germany, each voter gets two votes: one for a candidate (first vote) and one for a party (second vote). While the second vote determines parties' seat shares in parliament, the first vote is a winner-take-all contest, that is, the seat goes to the candidate with the most votes. ${ }^{4}$ Candidates running in these contests often show their title on campaign posters (see the online supporting information for examples). Most importantly, ballot papers prominently display the doctor's title as well as the professor's title next to a candidate's name (see the supporting information). In sum, it is not uncommon in Germany to observe academic titles outside academia, and they are frequently on display in politics.

\section{The Plagiarism Scandals}

During the 17th legislative period (2009-13), several prominent German politicians lost their doctorate after their dissertations had been judged plagiaries by their former universities. Table 1 gives an overview. The incidents received much attention in the German media. In the online supporting information, we provide sources for news coverage on the plagiarism scandals in German and international media outlets; we also provide links to the plagiarism wikies mentioned below.

The plagiarism scandals began in February 2011 when the Süddeutsche Zeitung (a major daily newspaper) reported that Andreas Fischer-Lescano, professor of law at the University of Bremen, found many uncited passages from other sources in the dissertation of minister of defense, KarlTheodor zu Guttenberg. Following these allegations, an anonymous activist created "GuttenPlag" a wiki where everyone could contribute sources for uncited passages they found in Guttenberg's dissertation. Subsequent contributions to GuttenPlag revealed that over $60 \%$ of Guttenberg's dissertation was made up of copied material without attribution of sources. The affair quickly grew into a public scandal, and within two weeks the University of Bayreuth revoked Guttenberg's doctorate and the minister resigned from all offices.

Six weeks after the Guttenberg case, newspaper reports pointed out problems with two other dissertations written by politicians. According to "VroniPlag," a wiki similar to GuttenPlag, the dissertations of Silvana Koch-Mehrin, then vice-president of the European Parliament, and Matthias Pröfrock, member of the state parliament of Baden-Württemberg, contained excessive amounts of copied material without proper citation. One month later, Jorgo Chatzimarkakis, MEP, and Bijan Djir-Sarai, member of the Bundestag, faced similar plagiarism allegations from VroniPlag. As with

\footnotetext{
4 The electoral system is "compensatory" in the sense that candidates elected in the first ballot cannot increase their party's share of seats beyond what the party is entitled to in terms of second votes. In filling parliamentary seats, however, directly elected candidates come first while candidates from party lists are considered only after all direct mandates (299 in total) have been allocated (for further information, see, e.g., Farrell, 2001).
} 


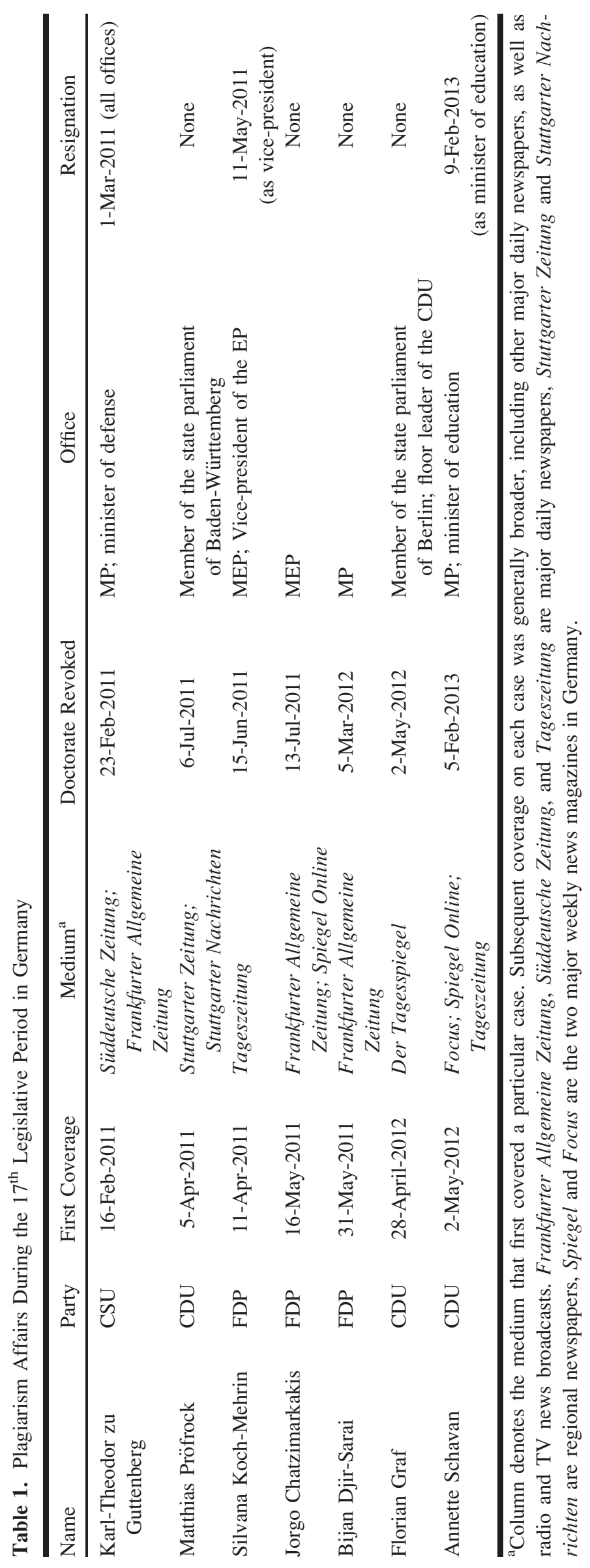


Guttenberg, these cases were broadly discussed in newspapers, news magazines, talk shows, and news broadcasts. By mid-July, Koch-Mehrin, Chatzimarkakis, and Pröfrock had lost their degrees. Eight months later, the University of Cologne also revoked Djir-Sarai's degree.

The last incidents in this series of plagiarism affairs began two months after Djir-Sarai lost his degree. In late April 2012, Florian Graf, floor leader of the CDU in the state parliament of Berlin, announced that he had violated academic standards in crafting his dissertation and requested that the University of Potsdam revoke his degree. His request was met within a week. In early May 2012, news magazines Focus and Spiegel Online, as well as the Tageszeitung (another major daily newspaper) published plagiarism allegations raised on "SchavanPlag"-a Vroniplag spinoff-against the dissertation of Annette Schavan, then minister of education. According to SchavanPlag, the dissertation contained unsourced material in about $30 \%$ of its pages. A subsequent review of the dissertation, initiated by the University of Düsseldorf, brought a similar verdict, and in May 2013, only four months before the next election, the University of Düsseldorf revoked Schavan's doctorate and the minister stepped down.

Plagiarism by politicians in pursuit of the doctorate was virtually unheard of in Germany prior to the scandals. The sudden burst of incidents over the course of a two-year period stirred a lot of attention. While some incidents were covered less prominently (e.g., Pröfrock \& Graf), at least four, Guttenberg, Koch-Mehrin, Chatzimarkakis, and Schavan, received a great deal of attention.

\section{Hypotheses}

Why would voters pick a candidate with an academic title? We surmise that voters hold a positive stereotype about the bearers of such titles. Since academic credentials are seen as an achievement and respected inside and outside academia, it seems likely that voters hold a positive image of people who possess such credentials. Surveys show that voters in Bundestag elections are not very knowledgeable about the candidates in their constituency (Maier, 2000). Many voters cannot name a single candidate in their district (Schmitt-Beck, 1993). Since ballot papers prominently display candidates' academic titles (see the online supporting information), voters have an opportunity to select candidates based on titles. Judging an unknown candidate who bears an academic title, voters might thus categorize her as academic, rather than, say, female, and rate her accordingly (Macrae \& Bodenhausen, 2000; Macrae, Milne, \& Bodenhausen, 1994). If German voters hold a positive image of academics, they should be more likely to favor candidates with academic titles, all else equal:

H1: Academic titles (Dr. and Prof.) are associated with an increase in a candidate's vote share.

Prior analyses of German voting behavior tend to support this hypothesis (see the supporting information for further discussion). For instance, among all directly elected Members of the Bundestag between 1949 and 2009, those with a doctor's degree obtained a larger share of first votes, on average, than those without a doctor's degree (Manow \& Flemming, 2011). Likewise, prior research suggests that electoral candidates with a doctor's title won more first votes than candidates without such a title at recent Bundestag elections (Klein \& Rosar, 2005; Mackenrodt, 2008; Schneider \& Tepe, 2011; but see also Jäckle and Metz, 2016), state parliament elections (Faas \& Schoen, 2006; Rosar, Klein, \& Beckers, 2008), mayoral elections (Rosar, Klein, \& Beckers, 2012), and municipal elections (Mechtel, 2014).

How might the plagiarism scandals affect voter judgments? The scandals presented voters with several negative examples of politicians with doctor's degrees. Based on our discussion of stereotype 
change, we expect voters to generalize from these examples to other politicians with a doctor's degree. If so, candidates with a doctor's title should be evaluated less favorably after the plagiarism scandals than before, holding all else constant:

H2: The vote advantage of candidates with a doctor's title decreases after the plagiarism scandals.

It bears noting that Hypothesis 2 allows for three possibilities: a reduced electoral advantage; a disappearing electoral advantage; and an electoral disadvantage for candidates with a doctor's degree compared to those without. An electoral disadvantage would result if voters in 2013 avoided candidates with a doctor's degree.

Our foregoing discussion of subtyping suggests that voters should find it easier to explain away deviant cases if those cases share other, formally neutral, attributes. One thing all the candidates who were implicated in the scandals had in common is membership in a right-wing party. In particular, they all belonged to one of the three parties that traditionally represent middleclass values in Germany: the Christian democratic CDU and CSU (from Bavaria), as well as the liberal FDP. One attempt to explain the plagiarism affairs, which was also hinted at in news stories, is that politicians from middle-class parties seek the doctorate mainly as a trophy-a means to boost their status within the party and impress voters. In response to such arguments, voters might have fenced-off right-wing politicians with a doctor's degree as "not truly academic." If so, one would expect the plagiarism scandals to affect only the electoral advantage of right-wing candidates with a doctor's title:

H3: The vote advantage of candidates who bear a doctor's title and belong to the CDU, the CSU, or the FDP decreases after the plagiarism scandals.

\section{Identification and Estimation}

We analyze the share of votes that each candidate received in the constituency at the 2009 and 2013 Bundestag elections. Data were obtained from the Federal Returning Officer (Bundeswahlleiter). We consider all candidates who stood for election and exclude only those candidates who did not affiliate with any party, or whose party did not appear on the party ballot (187 in 2009 and 191 in 2013). The reason for excluding those candidates is that we cannot properly control for their party's support in the district, that is, we cannot control for their party's share of votes (see below). This leaves us with a total of 2,008 and 2,514 candidates in 2009 and 2013, respectively.

\section{Estimating the Effect of Academic Titles}

To identify the effect of academic titles, we employ cross-sectional regressions with fixed effects for each constituency. The fixed-effects estimator suggests itself naturally in this context, as it avoids comparisons of vote shares across districts. Because voters can only choose among the candidates in their constituency, a title can only increase the vote share of a candidate relative to his or her competitors in the constituency. This means that inferences about the electoral effect of titles should be based solely on comparisons of candidates from the same constituencies. The fixed-effects approach does exactly that. By using deviations of the dependent and independent variables from their respective constituency means, it estimates the effects of the doctorate and all other independent variables solely 
Table 2. Candidates With Titles Running in the 2009 and 2013 Bundestag Elections ${ }^{\mathrm{a}}$

\begin{tabular}{lcccc}
\hline Election & Dr. $^{\text {b }}$ & Prof. & Title of Nobility $^{c}$ & No Title \\
\hline 2009 & 211 & 14 & 14 & 1774 \\
& $11 \%$ & $0.7 \%$ & $0.7 \%$ & 2230 \\
2013 & 248 & 15 & 24 & 632 \\
$2009 \& 2013$ & $10 \%$ & $0.6 \%$ & $7 \%$ & 7 \\
& 98 & 6 & $0.9 \%$ & $6 \%$ \\
\hline
\end{tabular}

${ }^{a}$ The table includes only those candidates who entered the regression analysis; this excludes, for example, nonpartisan candidates and candidates whose party did not run in the given state (see text).

${ }^{\text {b}}$ Candidates with a professor's title are excluded from the count.

${ }^{c}$ Five candidates with nobility titles also possess a doctor's degree in 2009 and three in 2013; three candidates who stood at both elections possess a title of nobility as well as a doctor's degree; no candidate with a nobility title holds a professor's title.

based on within-constituency comparisons (cf. Allison, 2009; Wooldridge, 2010). ${ }^{5}$ For reference, we also run regressions with random effects (RE) for each constituency and simple OLS regressions without constituency-specific intercepts.

The main independent variable is the doctor's title. In addition, we also code the professor's title and a title of nobility. Table 2 shows the number of individuals with a given title in the two samples that we analyze. As can be seen, a substantial share of candidates at each election holds a doctorate.

In estimating the effect of titles on election results, we take into account a range of potential confounders, which are discussed in detail in the online supporting information. Controls include the share of second votes for a candidate's party in the district, fixed effects for the five major parties which are allowed to differ for East and West Germany, ${ }^{6}$ candidate prominence, district incumbency, MP status, placement on a party list, age, gender, and occupation. Should we find an effect of titles in addition to these explanatory factors this would be an indication that voters favor candidates with academic credentials.

\section{Estimating the Effect of the Plagiarism Scandals}

To identify the effect of the plagiarism scandals, we employ two estimation approaches. The first approach compares the cross-sectional estimates of the effect of the doctorate in 2009 and 2013. The second approach identifies the effect of the plagiarism scandals by using a difference-in-differences (DID) estimator (Angrist \& Pischke, 2008; Wooldridge, 2010).

The cross-sectional approach estimates the effect of the doctor's degree by comparing candidates with a doctorate to those without a doctorate in the same election. A downside of this approach is that the sets of candidates in 2009 and 2013 differ as new candidates entered in 2013 while others dropped out. In order to identify the effect of the plagiarism scandals, we thus need to assume that, conditional on our controls, the candidates in 2013 and 2009 are exchangeable (i.e., the two sets of candidates do not differ systematically in unobserved attributes related to electoral success).

The DID estimator relaxes this assumption. It focuses on candidates who stood at both elections and compares their vote shares before and after the plagiarism scandals. Candidates with a doctorate can be thought of as the "treatment group" and candidates without a doctorate as the "control group" (cf. Bechtel \& Hainmueller, 2011). If the plagiarism scandals had an effect, the treated group should

\footnotetext{
5 Mean-differencing all variables with respect to their constituency means is equivalent to including dummy variables for each constituency in the model (Allison, 2009). We used Stata's xtreg command for the estimation.

${ }^{6}$ Not separating party fixed effects by region yields essentially the same results (see Tables S4 and S5 in the online supporting information).
} 
perform worse than the control group when we look at each group's change in vote share between elections. By considering the same individuals across elections, the DID estimator essentially controls for all time invariant unobserved attributes that are related to candidates' electoral success and hence relaxes the above-mentioned exchangeability assumption (Angrist \& Pischke, 2008, 221-243). ${ }^{7}$ To maximize comparability further, we only consider candidates who stood in the same constituencies and hence faced the same electorate at both elections. ${ }^{8}$ This leaves us with 739 candidates for the DID analysis. Table 2 (third row) shows a breakdown of the data with regard to the main variables of interest.

A potential downside of the DID estimator compared to the cross-sectional estimator in the current setting arises from the fact that electoral competition may change between elections. For example, a candidate's vote share in the district might change due to the entry or exit of other competitors. The DID estimator only looks at candidates who compete in both elections. Unlike the cross-sectional estimator, it hence does not account for the strength of electoral competitors in the district.

To control for changes in electoral competition in the DID design, we include the change in the number of candidates in each district as a control variable. In addition, we also control for the change in the number of candidates with a doctor's degree. While both variables are not ideal measures of change in district-level competition, they at least account for over-time variation in the field of candidates. To identify the effect of the plagiarism scandals in the DID design, we need to assume that, conditional on our controls, candidates with a doctor's degree in 2009 did not experience greater electoral competition in their districts in 2013 than candidates without a doctor's degree.

In addition to changes in district-level competition, we also control for the change over time in the share of second votes, incumbency status, MP status, being a top politician, being on the party list, and age. Furthermore, we estimate separate effects for candidates with a doctor's title, candidates with a professor's title, and candidates with a title of nobility. Finally, we include a set of party dummies, stratified by region, to allow for party- and region-specific trends in election results.

In sum, both outlined approaches to estimating the effect of the plagiarism scandals have their strengths and potential weaknesses. Since neither approach seems clearly superior, we employ both. If the plagiarism scandals exert a meaningful effect on voting behavior, we would expect the effect to show up under both approaches.

\section{Results}

\section{The Effect of Academic Titles}

Do German voters have a taste for academic titles? Our estimates suggest yes. As Figure 1 (lefthand side) shows, candidates with a doctor's degree won about half a percentage point $(0.59)$ more in votes than their competitors in 2009 . With an average of roughly 147,000 votes cast in each district in 2009 , this corresponds to over 800 additional votes. ${ }^{9}$ The difference is statistically significant ${ }^{10}$ and in line with previous findings (Schneider \& Tepe, 2011). The result is the same when we use random effects regression or ordinary linear regression (see Table A1 in the appendix). In 2013, candidates with a doctor's degree won a third of a percentage point $(0.33)$ more in votes than their competitors.

${ }^{7}$ We excluded 10 candidates who were listed with a doctor's title in only one of the two elections and one candidate who was listed with a professor's title in 2013 but not in 2009.

${ }^{8}$ Minor boundary revisions between 2009 and 2013 resulted in some candidates facing a different electorate in 2013. We exclude these from the analysis (137 candidates).

${ }^{9}$ Eight districts in 2009 and nine in 2013 were won by a margin of fewer than 800 votes.

${ }^{10}$ We follow standard practice in using statistical hypothesis tests, even though the data set comprises the "total population" of district candidates (minus candidates without a party affiliation). See the online supporting information for further discussion of this approach. 


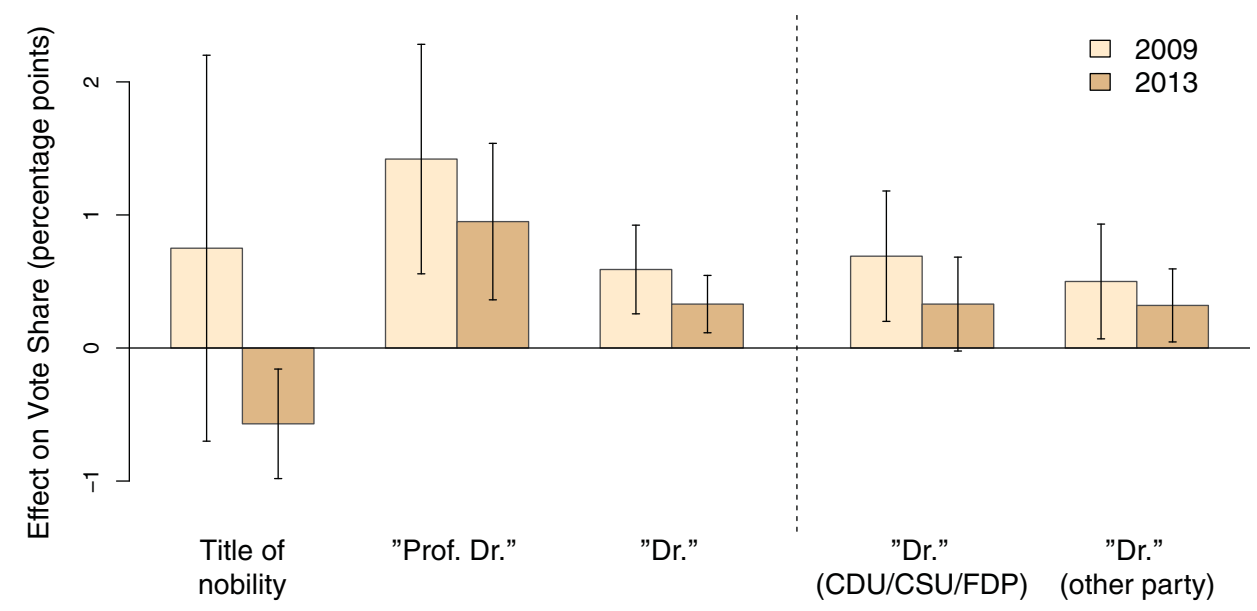

Figure 1. The effect of titles on vote share in the 2009 and 2013 elections. The left-hand side of the graph shows estimates from cross-sectional regressions of the share of first votes on candidate attributes in 2009 and 2013 (Table A1, cols. 1 and 2). The right-hand side of the graph shows results from cross-sectional regressions in which the effect of the doctor's title is estimated separately for those candidates who belong to the CDU, the CSU, or the FDP and candidates from other parties (see Table A3, cols. 1 and 2). Ninety-five percent confidence intervals (based on clustered standard error calculations) are superimposed. [Color figure can be viewed at wileyonlinelibrary.com]

Again, the result is significantly different from zero and substantially similar across model specifications.

Voter's taste for academic titles is further evidenced by the significant effect of the professor's title and the insignificant effect of nobility titles. Having a professor's title printed on the ballot wins a candidate something in the range of a full percentage point at each election. By comparison, being a member of the Bundestag wins a candidate about 0.9 percentage points (see Table A1). As a note of caution, we should add that few candidates actually hold a professor's title (see Table 2). Due to the small number of observations, estimates of the effect of the professor's title might be exaggerated. Nevertheless, the estimated effects at both elections point in the same direction, and they indicate a vote gain from holding a professor's title. Unlike an academic title, a noble title does not seem to help candidates at the ballot box. The effect of noble titles on vote share is positive but insignificant in 2009 and negative and statistically significant in 2013. If anything, voters seem to dislike nobility. However, as with professors, there are few candidates with a noble title (see Table 2), hence our estimates might be inflated. A pooled analysis (not shown) reveals no significant difference between a noble title's estimated positive effect in 2009 and its estimated negative effect in 2013.

\section{The Effect of the Plagiarism Scandals}

Did the advantage of candidates with a doctor's title decrease after the plagiarism scandals? At first sight, it seems that the plagiarism scandals had an effect (Figure 1, left-hand side): Compared to 2009 , the vote advantage of candidates with a doctorate in 2013 is reduced by about a quarter of a percentage point or, more precisely, by $44 \%$. Yet, this decrease could also result from natural variation in election results. To determine statistical significance, we estimated a pooled model in which each variable was interacted with election year. The interaction effect $\operatorname{Dr} \times 2013$ did not reach statistical significance at the $5 \%$ level. We also estimated a more restrictive pooled model in which only the Dr.-indicator, but no other variable, was interacted with election year. Again, the interaction effect was not statistically significant. The same conclusions hold for pooled estimations of a random effects model or a simple linear regression model. ${ }^{11}$

${ }^{11}$ Results of the pooled estimations are largely redundant to those reported in Table A1 and hence were omitted. 


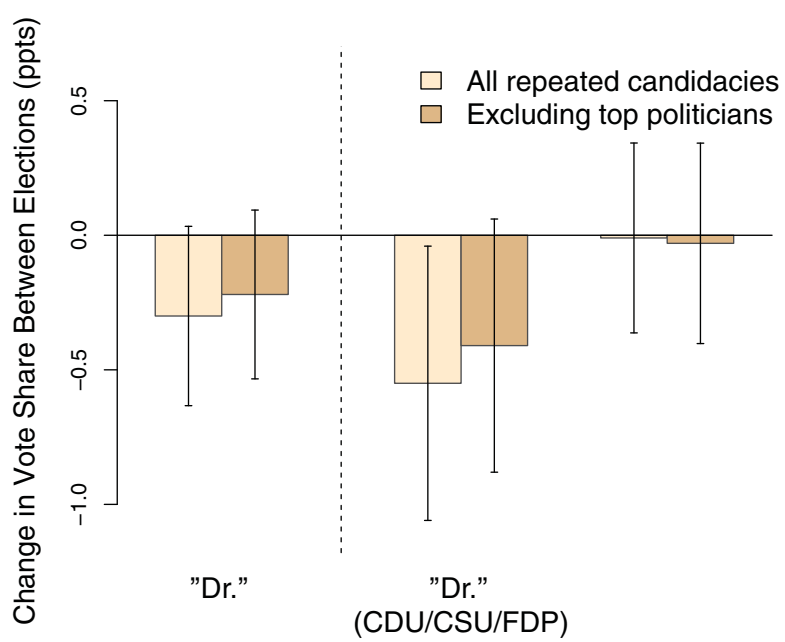

Figure 2. No significant effect of the plagiarism scandals. The left-hand side of the graph shows difference-indifferences (DID) estimates of the effect of the plagiarism scandals on the vote share of candidates with a doctor's title (Table A2, cols. 1 and 2). The right-hand side of the graph shows results from similar DID regressions that estimate the effect of the doctor's title separately for those candidates who belong to the CDU, the CSU, or the FDP and candidates from other parties (Table A2, cols. 3 and 4). Ninety-five percent confidence intervals (based on clustered standard error calculations) are superimposed. [Color figure can be viewed at wileyonlinelibrary.com]

Figure 2 shows the results of the DID estimation. Here we only consider candidates who stood at both elections, and we expect those with a doctorate to perform worse in 2013 than in 2009 compared to those without a doctorate. In line with the cross-sectional estimates, the DID regression shows a decrease in votes for candidates with a doctorate between 2009 and 2013 (Figure 2, left-hand side). Specifically, candidates with a doctor's degree lost one third of a percentage point, on average, in 2013. The estimate is not statistically significant, however.

Hypothesis 3 suggests that the effect of the plagiarism scandals might be restricted to candidates from the traditional middle-class parties (i.e., the two Christian democratic parties and the liberal FDP). According to Figure 1 (right-hand side), the reduction in the vote advantage of candidates with a doctor's title was indeed larger if those candidates belonged to the CDU, the CSU, or the FDP, rather than some other party. Yet, the difference is far from statistically significant. Testing Hypothesis 3 with the DID approach yields essentially the same result (Figure 2, right-hand side): Christian democratic and liberal candidates with a doctor's title experienced a reduction in their vote share while other candidates with a doctor's title did not. While the pattern is in line with Hypothesis 3, the difference does not reach statistical significance. The only significant contrast that we find is a reduction in the vote share of candidates from the three middle-class parties compared to the null hypothesis of no change.

As a check of robustness of this latter finding, we reestimated the DID model excluding top leading politicians from the sample (see Figure 2). Unlike ordinary politicians, top politicians' vote shares are more likely to depend on public approval than on ballot paper cues. If so, their vote shares are likely to vary more between elections than those of ordinary candidates. Top politicians could hence be driving the observed effect. After excluding candidates who were top politicians at one or both elections, the estimated effect of the plagiarism scandals on the vote share of candidates from the CDU, the CSU, or the FDP shrinks to one-third of a percentage point, which is about the same reduction that we find in the cross-sectional estimation approach. Furthermore, the estimate is not significantly different from zero anymore. ${ }^{12}$

\footnotetext{
${ }^{12}$ Excluding top politicians from the cross-sectional analyses does not affect our results.
} 
As another check on our findings, we tested Hypothesis 3 separately for candidates from the $\mathrm{CDU}$ and CSU, on the one hand, and candidates from the FDP, on the other hand. One might argue that the doctor's degree is used by (undecided) voters mainly as a cue to determine which one of the two candidates who have the best chances of winning they should choose. The plagiarism scandals would then affect candidates from the CDU and CSU more than candidates from the FDP. Our results (see Tables S2 and S3 in the online supporting information) again suggest that the plagiarism scandals had no effect: While the vote advantage of CDU and CSU candidates who hold a doctor's degree shrinks between 2009 and 2013, the reduction is not statistically significant.

\section{Discussion}

Stereotypes about other people can influence electoral decisions. We investigated whether exposure to a spate of salient counterexamples can reduce the influence of stereotypes on voting. We found that candidates with academic titles (Dr. or Prof.) enjoyed a statistically significant and substantively relevant electoral advantage at German Bundestag elections despite a series of seven academic plagiarism scandals. We found that candidates with doctor's degrees did perform worse after the scandals, and, in line with a subtyping argument, we found that the reduction pertained mainly to candidates from traditional middle-class parties (i.e., the parties of the candidates who were implicated in the scandals). However, neither of these effects was strong enough to reach statistical significance across a variety of possible tests. Thus, the evidence does not provide sufficient support for the conclusion that voters behaved markedly differently in both elections toward candidates with a doctor's title. Apparently, seven scandals in one legislative term are not enough to produce a noticeable change in voters' stereotypes about politicians with doctor's titles. Our results are in line with previous findings which suggest that salient examples of counterstereotypic politicians have little effect on voter biases (cf. Pasek et al., 2014; Schmidt \& Nosek, 2010).

Why did the scandals have no effect? One argument could be that candidates with doctor's titles tried to prevent potential vote losses from the scandals. We do not think that this explains the lack of effect. First, there were no attempts (that we know of) by candidates with doctor's titles to distance themselves from the plagiarizers or to portrait themselves as "genuine doctors" either during their campaigns or at the time the scandals occurred. Second, if candidates with doctor's titles chose to downplay their doctorate in their campaigns for fear of electoral punishment, then this would have actually worked in favor of finding an effect. For example, if fewer candidates displayed their title on campaign posters in 2013, we would have expected a reduction in their electoral advantage. The fact that we observe no significant reduction in the electoral advantage of candidates with doctor's titles means either those candidates did not change their campaign behavior ${ }^{13}$ and voters continued to favor them, or attempts to downplay the doctor's title had no effect on voting, most likely because ballot papers still show titles on the day of election. Either way, the scandals had no effect on voters' decisions.

Why did the scandals not affect voter stereotypes? Unlike studies of racial voting bias (e.g., Goldman, 2012; Hutchings, 2009; Pasek et al., 2014), we cannot examine what microlevel processes give rise to the (lack of) pattern in the aggregate election result. While survey data is available for both elections, they do not contain precise measures of voters' esteem for academic credentials. Absent such information, tests of possible microlevel processes would not be very powerful. Hence, at this point, we can only speculate about an answer.

One reason could be that voters considered the politicians who were implicated in the scandals to be different from other politicians with a doctorate. For example, the cases that generated the most

${ }^{13}$ Personal experience suggests that some candidates show their academic titles on campaign posters while others do not. Unfortunately, there is no archive for the thousands of campaign posters in the 2009 and 2013 elections that we could draw on to determine whether the Dr. was used less often after the scandals. 
attention (Guttenberg, Koch-Mehrin, \& Schavan) all involved politicians in top positions, who might be seen as more ambitious or career-oriented than the average constituency candidate in Bundestag elections. More generally, the extensive media coverage on the plagiarism affairs provided a great deal of individuating information about the offenders, which voters could have used to explain away their deviant behavior (cf. Kunda \& Oleson, 1995). If this is true, media coverage about deviant behavior might be a double-edged sword: While it provides stereotype-disconfirming information that is needed to trigger stereotype change, at the same time the detailed background stories that usually surround such reports may inhibit stereotype change.

Another reason for the lack of effect could be that voters did not perceive a significant benefit from revising their stereotypes (Moreno \& Bodenhausen, 1999). For instance, Lupia et al. (2015) suggest that prejudice reduction will only occur if citizens observe counterstereotypical information and realize that stereotype revision will enable them to make better decisions in the future. Thus, a voter who depends on city services and observes that a black mayor provides these effectively should be more inclined to revise her racial stereotype than a voter who does not depend on such services (Lupia et al., 2015, p. 16). Although dishonesty in politicians is considered undesirable, and despite public outcries in the wake of the scandals, the possibility of electing academic phonies in the future might not have appeared threatening enough to voters to warrant a change of mind.

Finally, the classic two-step flow hypothesis by Lazarsfeld, Berelson, and Gaudet (1965, pp. 151-152) offers another possible explanation for voters' mild reactions towards plagiarizing politicians. While the plagiarism scandals were widely covered in the media (see Table 1), the second-step coverage by other relevant actors, "opinion leaders" in the terminology of Lazarsfeld et al. (1965), was relatively modest. In particular, there was very little criticism by other politicians. ${ }^{14}$ Critics were to be found mainly among the scientific community and journalists. Perhaps voters, especially those unfamiliar with the codes of academia, therefore did not consider these incidents particularly severe.

If public scandals such as the ones studied here do not change voters' reliance on academic credentials, incentives for politicians to commit academic fraud will persist. Removing titles from ballot papers might be one way to reduce their effect in elections, but as long as voters value titles, candidates will have an incentive to use them in electoral advertising. It bears noting in this regard that Germany is not the only country that has witnessed allegations of academic plagiarism against leading politicians in the recent past. For instance, Hungarian president Pal Schmitt stepped down on April 2, 2012, a week after it became clear that his dissertation was plagiarized. Allegations of plagiarism also brought down Romania's education minister Ioan Mang in 2012 and led to an investigation of Romanian prime minister Victor Ponta's dissertation, which confirmed that parts of his thesis were copied without attribution. Our results suggest that public scandals such as these will do little to reduce politicians' incentives to obtain a fake doctorate for electoral gain.

\section{ACKNOWLEDGMENTS}

We thank Julian Garritzmann, Roos van der Haer, Niklas Harder, Konstantin Käppner, Constantin Ruhe, Ansgar Schäfer, Ulrich Sieberer, Michael Stoffel, and the reviewers for helpful feedback and comments. Correspondence concerning this article should be addressed to Michael Herrmann, University of Konstanz, Department of Politics and Public Administration, Box 92, 78457 Konstanz, Germany. E-mail: michael.herrmann@uni-konstanz.de

\footnotetext{
${ }^{14}$ One of the few politicians who openly disapproved of Karl Theodor zu Guttenberg's behavior was Annette Schavan, then minister of science and education, who said that "she was more than just secretly ashamed of him." Schavan later was also found guilty of plagiarism.
} 


\section{REFERENCES}

Allison, P. D. (2009). Fixed effects regression models. Thousand Oaks, CA: Sage.

Allport, G. W. (1979). The nature of prejudice. Reading, MA: Basic Books.

Angrist, J. D., \& Pischke, J.-S. (2008). Mostly harmless econometrics: An empiricist's companion. Princeton, NJ: Princeton University Press.

Arzheimer, K., \& Evans, J. (2012). Geolocation and voting: Candidate-voter distance effects on party choice in the 2010 UK general election in England. Political Geography, 31(5), 301-310.

Auriol, L. (2007). Labour market characteristics and international mobility of doctorate holders: Results for seven countries. OECD Science, Technology and Industry Working Papers, 2007/02.

Banducci, S. A., Karp, J. A., Thrasher, M., \& Rallings, C. (2008). Ballot photographs as cues in low-information elections. Political Psychology, 29(6), 903-917.

Basinger, S. J. (2013). Scandals and congressional elections in the post-Watergate era. Political Research Quarterly, 22(2), 385-398

Bechtel, M. M., \& Hainmueller, J. (2011). How lasting is voter gratitude? An analysis of the short-and long-term electoral returns to beneficial policy. American Journal of Political Science, 55(4), 852-868.

Bhatti, Y., Hansen, K., \& Olsen, A. L. (2013). Political hypocrisy: The effect of political scandals on candidate evaluations. Acta Politica, 48(4), 408-428.

Blair, I. V. (2002). The malleability of automatic stereotypes and prejudice. Personality and Social Psychology Review, 6(3), 242-261.

Bless, H., \& Schwarz, N. (1998). Context effects in political judgement: Assimilation and contrast as a function of categorization processes. European Journal of Social Psychology, 28(2), 159-172.

Bless, H., Schwarz, N., Bodenhausen, G. V., \& Thiel, L. (2001). Personalized versus generalized benefits of stereotype disconfirmation: Trade-offs in the evaluation of atypical exemplars and their social groups. Journal of Experimental Social Psychology, 37(5), 386-397.

Bodenhausen, G. V., Schwarz, N., Bless, H., \& Wänke, M. (1995). Effects of atypical exemplars on racial beliefs: Enlightened racism or generalized appraisals. Journal of Experimental Social Psychology, 31(1), 48-63.

Bowler, S., \& Karp, J. A. (2004). Politicians, scandals, and trust in government. Political Behavior, 26(3), 271-287.

Buckley, F., Collins, N., \& Reidy, T. (2007). Ballot paper photographs and low-information elections in Ireland. Politics, 27(3), 174-181.

Chaxel, A.-S. (2015). How do stereotypes influence choice? Psychological Science, 26(5), 641-645.

Columb, C., \& Plant, E. A. (2011). Revisiting the Obama effect: Exposure to Obama reduces implicit prejudice. Journal of Experimental Social Psychology, 47(2), 499-501.

Dasgupta, N., \& Asgari, S. (2004). Seeing is believing: Exposure to counterstereotypic women leaders and its effect on the malleability of automatic gender stereotyping. Journal of Experimental Social Psychology, 40(5), 642658.

Dasgupta, N., \& Greenwald, A. G. (2001). On the malleability of automatic attitudes: Combating automatic prejudice with images of admired and disliked individuals. Journal of Personality and Social Psychology, 81(5), 800.

Eggers, A. (2014). Partisanship and electoral accountability: Evidence from the UK expenses scandal. Quarterly Journal of Political Science, 9(4), 441-472.

Faas, T., \& Schoen, H. (2006). The importance of being first: Effects of candidates' list positions in the 2003 Bavarian state election. Electoral Studies, 25, 91-102.

Farrell, D. M. (2001). Electoral systems. A comparative introduction. Basingstoke, United Kingdom: Palgrave Macmillan.

Festinger, L. (1957). A theory of cognitive dissonance. Stanford, CA: Stanford University Press.

Fisher, S. D., Heath, A. F., Sanders, D., \& Sobolewska, M. (2015). Candidate ethnicity and vote choice in Britain. British Journal of Political Science, 45(04), 883-905.

Funk, C. L. (1996). The impact of scandal on candidate evaluations: An experimental test of the role of candidate traits. Political Behavior, 18(1), 1-24.

Giger, N., Holli, A. M., Lefkofridi, Z., \& Wass, H. (2014). The gender gap in same-gender voting: The role of context. Electoral Studies, 35(3), 303-314.

Goldman, S. K. (2012). Effects of the 2008 Obama presidential campaign on White racial prejudice. Public Opinion Quarterly, 76(4), 663-687. 
Henderson-King, E. I., \& Nisbett, R. E. (1996). Anti-Black prejudice as a function of exposure to the negative behavior of a single Black person. Journal of Personality and Social Psychology, 71(4), 654.

Hewstone, M., Johnston, L., \& Aird, P. (1992). Cognitive models of stereotype change: Perceptions of homogeneous and heterogeneous groups. European Journal of Social Psychology, 22(3), 235-249.

Hewstone, M., Macrae, C. N., Griffiths, R., Milne, A. B., \& Brown, R. (1994). Cognitive models of stereotype change. Measurement, development, and consequences of subtyping. Journal of Experimental Social Psychology, 30(6), $505-526$.

Holli, A., \& Wass, H. (2010). Gender-based voting in the parliamentary elections of 2007 in Finland. European Journal of Political Research, 49(5), 598-630.

Huddy, L., \& Capelos, T. (2002). Gender stereotyping and candidate evaluation. In V. C. Ottati, R. S. Tindale, J. Edwards, F. B. Bryant, L. Health, D. C. O’Connell, et al. (Eds.), The social psychology of politics (pp. 29-53, Social Psychological Applications to Social Issues). Boston, MA: Springer.

Hutchings, V. L. (2009). Change or more of the same? Evaluating racial attitudes in the Obama era. Public Opinion Quarterly, 73(5), 917-942.

Jäckle, S., \& Metz, T. (2016). Brille, Blazer oder Bart? Das Aussehen als Determinante des Wahlerfolgs von Bundestags-Direktkandidaten. Politische Vierteljahresschrift, 57(2), 217-246.

Jacobsmeier, M. L. (2015). From Black and White to left and right: Race, perceptions of candidates' ideologies, and voting behavior in U.S. House elections. Political Behavior, 37(3), 595-621.

Johnston, L., \& Hewstone, M. (1992). Cognitive models of stereotype change. Journal of Experimental Social Psychology, 28(4), 360-386.

Jurajda, S., \& Münich, D. (2015). Candidate ballot information and election outcomes: The Czech case. Post-Soviet Affairs, 31(5), 448-469.

Kelley, J., \& McAllister, I. (1984). Ballot paper cues and the vote in Australia and Britain: Alphabetic voting, sex, and Title. Public Opinion Quarterly, 48(2), 452-466.

Klein, M., \& Rosar, U. (2005). Physische Attraktivität und Wahlerfolg. Eine empirische Analyse am Beispiel der Wahlkreiskandidaten bei der Bundestagswahl 2002. Politische Vierteljahresschrift, 46(2), 263-287.

Koch, J. W. (2002). Gender stereotypes and citizens' impressions of House candidates' ideological orientations. American Journal of Political Science, 46(2), 453-462.

Kunda, Z. (1990). The case for motivated reasoning. Psychological Bulletin, 108(3), 480-498.

Kunda, Z., \& Oleson, K. C. (1995). Maintaining stereotypes in the face of disconfirmation: Constructing grounds for subtyping deviants. Journal of Personality and Social Psychology, 68(4), 565-579.

Lau, R. R., \& Redlawsk, D. P. (2001). Advantages and disadvantages of cognitive heuristics in political decision making. American Journal of Political Science, 45(4), 951-971.

Lau, R. R., \& Sears, D. O. (1986). Political cognition. Hillsdale, NJ: Lawrence Erlbaum.

Lazarsfeld, P. F., Berelson, B., \& Gaudet, H. (1965). The people's choice: How the voter makes up his mind in a presidential campaign (2nd ed.). New York, NY: Columbia University Press.

Lupia, A., Casey, L. S., Karl, K. L., Piston, S., Ryan, T. J., \& Skovron, C. (2015). What does it take to reduce racial prejudice in individual-level candidate evaluations? A formal theoretic perspective. Political Science Research and Methods, 3(01), 1-20.

Mackenrodt, C. (2008). Wie wichtig ist die Person? Zur Bedeutung von Persönlichkeitsfaktoren von Wahlkreisbewerbern bei Bundestagswahlen. Zeitschrift für Parlamentsfragen, 39(1), 69-83.

Macrae, C. N., \& Bodenhausen, G. V. (2000). Social cognition: Thinking categorically about others. Annual Review of Psychology, 51(1), 93-120.

Macrae, C. N., Milne, A. B., \& Bodenhausen, G. V. (1994). Stereotypes as energy-saving devices: A peek inside the cognitive toolbox. Journal of Personality and Social Psychology, 66(1), 37.

Maier, J. (2000). Politisches Interesse und politisches Wissen in Ost- und Westdeutschland. In J. W. Falter, O. W. Gabriel, \& H. Rattinger (Eds.), Wirklich ein Volk? (pp. 141-171). Wiesbaden, Germany: VS Verlag für Sozialwissenschaften.

Maier, J. (2011). The impact of political scandals on political support: An experimental test of two theories. International Political Science Review, 32(3), 1-20.

Manow, P., \& Flemming, P. (2011). Der Titel als politisches Distinktionsmerkmal? Eine Untersuchung akademischer und adeliger Wahlbewerber zum Deutschen Bundestag 1949-2009. Zeitschrift für Politikwissenschaft, 21(4), 531-551

Marcinkiewicz, K. (2014). Electoral contexts that assist voter coordination: Ballot position effects in Poland. Electoral Studies, 33, 322-334.

Maurer, K. L., Park, B., \& Rothbart, M. (1995). Subtyping versus subgrouping processes in stereotype representation. Journal of Personality and Social Psychology, 69(5), 812-824. 
McDermott, M. L. (1997). Voting cues in low-information elections: Candidate gender as a social information variable in contemporary United States elections. American Journal of Political Science, 41(1), 270-283.

McDermott, M. L. (2005). Candidate occupations and voter information shortcuts. Journal of Politics, 67(1), $201-219$.

McDermott, M. L. (2007). Voting for Catholic candidates: The evolution of a stereotype. Social Science Quarterly, 88(4), 953-969.

Mechtel, M. (2014). It's the occupation, stupid! Explaining candidates' success in low-information elections. European Journal of Political Economy, 33, 53-70.

Miller, B. (2010). The effects of scandalous information on recall of policy-related information. Political Psychology, 31(6), 887-914.

Miller, B. J., \& Lundgren, J. D. (2010). An experimental study of the role of weight bias in candidate evaluation. Obesity $18(4), 712-718$.

Mitchell, D-G. (2014). Here today, gone tomorrow? Assessing how timing and repetition of scandal information affects candidate evaluations. Political Psychology, 35(5), 679-701.

Moreno, K. N., \& Bodenhausen, G. V. (1999). Resisting stereotype change: The role of motivation and attentional capacity in defending social beliefs. Group Processes and Intergroup Relations, 2(1), 5-16.

Olivola, C. Y., Sussman, A. B., Tsetsos, K., Kang, O. E., \& Todorov, A. (2012). Republicans prefer Republican-looking leaders: Political facial stereotypes predict candidate electoral success among right-leaning voters. Social Psychological and Personality Science, 3(5), 605-613.

Pasek, J., Stark, T. H., Krosnick, J. A., Tompson, T., \& Payne, B. K. (2014). Attitudes toward blacks in the Obama era changing distributions and impacts on job approval and electoral choice, 2008-2012. Public Opinion Quarterly, 78(S1), 276-302.

Plant, E. A., Devine, P. G., Cox, W. T. L., Columb, C., Miller, S. L., Goplen, J., \& Peruche, B. M. (2009). The Obama effect: Decreasing implicit prejudice and stereotyping. Journal of Experimental Social Psychology, 45(4), 961-964.

Popkin, S. L. (1994). The reasoning voter: Communication and persuasion in presidential campaigns. Chicago, IL: University of Chicago Press.

Puente-Diaz, R. (2015). Can the same politician help and hurt the evaluations of another politician? The role of categorization on the elicitation of assimilation and contrast effects in the Mexican political context. Political Psychology, 36(4), 469-478.

Prior, M. (2014). Visual political knowledge: A different road to competence? Journal of Politics 76(1), 41-57.

Régner, I., \& Le Floch, V. (2005). When political expertise moderates the impact of scandals on young adults' judgments of politicians. European Journal of Social Psychology, 35(2), 255-261.

Richards, Z., \& Hewstone, M. (2001). Subtyping and subgrouping: Processes for the prevention and promotion of stereotype change. Personality and Social Psychology Review, 5(1), 52-73.

Rosar, U., Klein, M., \& Beckers, T. (2008). The frog pond beauty contest: Physical attractiveness and electoral success of the constituency candidates at the North Rhine-Westphalia state election of 2005. European Journal of Political Research, 47, 64-79.

Rosar, U., Klein, M., \& Beckers, T. (2012). Magic mayors: Predicting electoral success from candidates' physical attractiveness under the conditions of a presidential electoral system. German Politics, 21(4), 372-391.

Rudolph, L., \& Däubler, T. (2016). Holding individual representatives accountable: The role of electoral systems. Journal of Politics, 78(3), 746-762.

Schmidt, K., \& Nosek, B. A. (2010). Implicit (and explicit) racial attitudes barely changed during Barack Obama's presidential campaign and early presidency. Journal of Experimental Social Psychology, 46(2), 308-314.

Schmitt-Beck, R. (1993). Denn sie wissen nicht, was sie tun... Zum Verständnis des Verfahrens der Bundestagswahl bei westdeutschen und ostdeutschen Wählern. Zeitschrift für Parlamentsfragen, 24(3), 393-415.

Schneider, S., \& Tepe, M. (2011). Dr. Right and Dr. Wrong: Zum Einfluss des Doktortitels auf den Wahlerfolg von Direktkandidaten bei der Bundestagswahl 2009. Politische Vierteljahresschrift, 248-285.

Schwarz, N., \& Bless, H. (1992). Scandals and the public's trust in politicians: Assimilation and contrast effects. Personality and Social Psychology Bulletin, 18, 574-579.

Steenbergen, M. R. (2010). The new political psychology of voting. In T. Faas, K. Arzheimer, \& S. Roßteutscher (Eds.), Information - Wahrnehmung - Emotion (pp. 13-31). Wiesbaden, Germany: VS Verlag für Sozialwissenschaften.

Tavits, M. (2010). Effect of local ties on electoral success and parliamentary behaviour: The case of Estonia. Party Politics, 16(2), 215-235.

Todorov, A., Mandisodza, A. N., Goren, A., \& Hall, C. C. (2005). Inferences of competence from faces predict election outcomes. Science, 308(5728), 1623-1626. 
Valentino, N. A., Hutchings, V. L., \& White, I. K. (2002). Cues that matter: How political ads prime racial attitudes during campaigns. American Political Science Review, 96(01), 75-90.

Vivyan, N., Wagner, M., \& Tarlov, J. (2012). Representative misconduct, voter perceptions and accountability: Evidence from the 2009 House of Commons expenses scandal. Electoral Studies 31(4), 750-763.

Weber, R., \& Crocker, J. (1983). Cognitive processes in the revision of stereotypic beliefs. Journal of Personality and Social Psychology, 45(5), 961-977.

Wolf, S. (2013). Bribe and cheat to get a doctoral degree in Germany? Global Corruption Report: Education. London: Transparency International \& Routledge.

Wooldridge, J. M. (2010). Econometric analysis of cross section and panel data: Baltimore, MD: MIT press.

Yzerbyt, V. Y., Coull, A., \& Rocher, S. J. (1999). Fencing off the deviant: The role of cognitive resources in the maintenance of stereotypes. Journal of Personality and Social Psychology, 77(3), 449-462.

\section{Appendix: Full Regression Results}

Table A1. Linear Fixed Effects, Random Effects, and OLS Regressions of the Share of First Votes on Candidate Titles in the 2009 and 2013 Bundestag Elections

\begin{tabular}{|c|c|c|c|c|c|c|}
\hline & $\begin{array}{c}\mathrm{FE} \\
2009\end{array}$ & $\begin{array}{c}\mathrm{FE} \\
2013\end{array}$ & $\begin{array}{c}\mathrm{RE} \\
2009\end{array}$ & $\begin{array}{c}\mathrm{RE} \\
2013\end{array}$ & $\begin{array}{l}\text { OLS } \\
2009\end{array}$ & $\begin{array}{l}\text { OLS } \\
2013\end{array}$ \\
\hline Dr. & $\begin{array}{l}0.59 * * * \\
(0.17)\end{array}$ & $\begin{array}{l}0.33^{* *} \\
(0.11)\end{array}$ & $\begin{array}{l}0.49 * * * \\
(0.15)\end{array}$ & $\begin{array}{c}0.26^{*} \\
(0.11)\end{array}$ & $\begin{array}{l}0.49 * * * \\
(0.15)\end{array}$ & $\begin{array}{c}0.27 * \\
(0.11)\end{array}$ \\
\hline Prof. & $\begin{array}{l}1.42^{* *} \\
(0.44)\end{array}$ & $\begin{array}{l}0.95^{* *} \\
(0.30)\end{array}$ & $\begin{array}{l}1.11 * * \\
(0.40)\end{array}$ & $\begin{array}{l}0.92 * * * \\
(0.28)\end{array}$ & $\begin{array}{l}1.13 * * \\
(0.40)\end{array}$ & $\begin{array}{l}0.95 * * * \\
(0.28)\end{array}$ \\
\hline Noble title & $\begin{array}{c}0.75 \\
(0.74)\end{array}$ & $\begin{array}{c}-0.57 * * \\
(0.21)\end{array}$ & $\begin{array}{c}0.52 \\
(0.68)\end{array}$ & $\begin{array}{c}-0.53^{*} \\
(0.22)\end{array}$ & $\begin{array}{c}0.52 \\
(0.67)\end{array}$ & $\begin{array}{c}-0.52^{*} \\
(0.21)\end{array}$ \\
\hline Top politician & $\begin{array}{l}3.40 * * * \\
(0.76)\end{array}$ & $\begin{array}{l}1.88 * * \\
(0.71)\end{array}$ & $\begin{array}{l}2.89 * * * \\
(0.66)\end{array}$ & $\begin{array}{l}1.64 * * \\
(0.63)\end{array}$ & $\begin{array}{l}2.89 * * * \\
(0.66)\end{array}$ & $\begin{array}{c}1.65^{*} \\
(0.64)\end{array}$ \\
\hline District incumbent & $\begin{array}{l}3.04 * * * \\
(0.27)\end{array}$ & $\begin{array}{l}1.88 * * * \\
(0.27)\end{array}$ & $\begin{array}{l}2.88 * * * \\
(0.26)\end{array}$ & $\begin{array}{l}1.83 * * * \\
(0.26)\end{array}$ & $\begin{array}{l}2.88 * * * \\
(0.26)\end{array}$ & $\begin{array}{l}1.83^{* * * *} \\
(0.26)\end{array}$ \\
\hline MP & $\begin{array}{l}0.92 * * * \\
(0.18)\end{array}$ & $\begin{array}{l}0.86^{* * * *} \\
(0.15)\end{array}$ & $\begin{array}{l}0.74 * * * \\
(0.17)\end{array}$ & $\begin{array}{l}0.70 * * * \\
(0.14)\end{array}$ & $\begin{array}{l}0.74 * * * \\
(0.17)\end{array}$ & $\begin{array}{l}0.70 * * * \\
(0.13)\end{array}$ \\
\hline On party list & $\begin{array}{c}-0.09 \\
(0.10)\end{array}$ & $\begin{array}{r}-0.06 \\
(0.06)\end{array}$ & $\begin{array}{c}-0.13 \\
(0.08)\end{array}$ & $\begin{array}{r}-0.07 \\
(0.05)\end{array}$ & $\begin{array}{c}-0.12 \\
(0.08)\end{array}$ & $\begin{array}{c}-0.03 \\
(0.05)\end{array}$ \\
\hline Other occupation & $\begin{array}{l}0.00 \\
(.)\end{array}$ & $\begin{array}{l}0.00 \\
(.)\end{array}$ & $\begin{array}{l}0.00 \\
(.)\end{array}$ & $\begin{array}{l}0.00 \\
(.)\end{array}$ & $\begin{array}{l}0.00 \\
(.)\end{array}$ & $\begin{array}{l}0.00 \\
(.)\end{array}$ \\
\hline Agriculture & $\begin{array}{c}0.11 \\
(0.46)\end{array}$ & $\begin{array}{c}0.12 \\
(0.26)\end{array}$ & $\begin{array}{c}0.17 \\
(0.36)\end{array}$ & $\begin{array}{c}0.13 \\
(0.24)\end{array}$ & $\begin{array}{c}0.17 \\
(0.36)\end{array}$ & $\begin{array}{c}0.10 \\
(0.24)\end{array}$ \\
\hline Lower manual & $\begin{array}{c}0.08 \\
(0.13)\end{array}$ & $\begin{array}{c}0.02 \\
(0.14)\end{array}$ & $\begin{array}{c}0.10 \\
(0.11)\end{array}$ & $\begin{array}{c}0.05 \\
(0.13)\end{array}$ & $\begin{array}{c}0.10 \\
(0.11)\end{array}$ & $\begin{array}{c}0.04 \\
(0.13)\end{array}$ \\
\hline Higher manual & $\begin{array}{c}0.15 \\
(0.14)\end{array}$ & $\begin{array}{c}0.11 \\
(0.07)\end{array}$ & $\begin{array}{c}0.17 \\
(0.11)\end{array}$ & $\begin{array}{c}0.14 * \\
(0.06)\end{array}$ & $\begin{array}{c}0.16 \\
(0.11)\end{array}$ & $\begin{array}{c}0.16^{*} \\
(0.06)\end{array}$ \\
\hline Technical & $\begin{array}{r}-0.26 \\
(0.20)\end{array}$ & $\begin{array}{c}0.08 \\
(0.11)\end{array}$ & $\begin{array}{r}-0.19 \\
(0.17)\end{array}$ & $\begin{array}{c}0.04 \\
(0.11)\end{array}$ & $\begin{array}{r}-0.18 \\
(0.17)\end{array}$ & $\begin{array}{c}0.05 \\
(0.10)\end{array}$ \\
\hline Engineering & $\begin{array}{c}0.21 \\
(0.20)\end{array}$ & $\begin{array}{c}0.11 \\
(0.11)\end{array}$ & $\begin{array}{c}0.23 \\
(0.17)\end{array}$ & $\begin{array}{c}0.12 \\
(0.10)\end{array}$ & $\begin{array}{c}0.23 \\
(0.17)\end{array}$ & $\begin{array}{c}0.12 \\
(0.10)\end{array}$ \\
\hline Lower service & $\begin{array}{c}-0.02 \\
(0.20)\end{array}$ & $\begin{array}{r}-0.06 \\
(0.12)\end{array}$ & $\begin{array}{c}0.14 \\
(0.36)\end{array}$ & $\begin{array}{r}-0.03 \\
(0.11)\end{array}$ & $\begin{array}{c}0.15 \\
(0.35)\end{array}$ & $\begin{array}{c}-0.04 \\
(0.11)\end{array}$ \\
\hline Higher service & $\begin{array}{c}0.19 \\
(0.15)\end{array}$ & $\begin{array}{c}0.17 \\
(0.12)\end{array}$ & $\begin{array}{c}0.18 \\
(0.14)\end{array}$ & $\begin{array}{c}0.19 \\
(0.10)\end{array}$ & $\begin{array}{c}0.18 \\
(0.14)\end{array}$ & $\begin{array}{c}0.19 \\
(0.10)\end{array}$ \\
\hline Semi-professional & $\begin{array}{c}0.06 \\
(0.14)\end{array}$ & $\begin{array}{c}0.11 \\
(0.09)\end{array}$ & $\begin{array}{c}0.10 \\
(0.13)\end{array}$ & $\begin{array}{c}0.12 \\
(0.09)\end{array}$ & $\begin{array}{c}0.10 \\
(0.13)\end{array}$ & $\begin{array}{c}0.12 \\
(0.09)\end{array}$ \\
\hline Professional & $\begin{array}{r}-0.09 \\
(0.27)\end{array}$ & $\begin{array}{c}0.07 \\
(0.14)\end{array}$ & $\begin{array}{c}-0.00 \\
(0.24)\end{array}$ & $\begin{array}{c}0.14 \\
(0.13)\end{array}$ & $\begin{array}{c}0.00 \\
(0.24)\end{array}$ & $\begin{array}{c}0.10 \\
(0.13)\end{array}$ \\
\hline
\end{tabular}


Table A1. Continued

\begin{tabular}{|c|c|c|c|c|c|c|}
\hline & $\begin{array}{c}\text { FE } \\
2009\end{array}$ & $\begin{array}{c}\text { FE } \\
2013\end{array}$ & $\begin{array}{c}\mathrm{RE} \\
2009 \\
\end{array}$ & $\begin{array}{c}\mathrm{RE} \\
2013\end{array}$ & $\begin{array}{r}\text { OLS } \\
2009 \\
\end{array}$ & $\begin{array}{l}\text { OLS } \\
2013 \\
\end{array}$ \\
\hline Lo business/admin. & $\begin{array}{r}-0.28 \\
(0.21)\end{array}$ & $\begin{array}{c}-0.01 \\
(0.21)\end{array}$ & $\begin{array}{r}-0.17 \\
(0.17)\end{array}$ & $\begin{array}{c}-0.04 \\
(0.18)\end{array}$ & $\begin{array}{l}-0.16 \\
(0.17)\end{array}$ & $\begin{array}{c}0.02 \\
(0.18)\end{array}$ \\
\hline Hi business/admin. & $\begin{array}{c}0.03 \\
(0.14)\end{array}$ & $\begin{array}{c}0.12 \\
(0.08)\end{array}$ & $\begin{array}{r}-0.02 \\
(0.12)\end{array}$ & $\begin{array}{c}0.12 \\
(0.07)\end{array}$ & $\begin{array}{r}-0.02 \\
(0.12)\end{array}$ & $\begin{array}{c}0.12 \\
(0.07)\end{array}$ \\
\hline Management & $\begin{array}{c}-0.03 \\
(0.18)\end{array}$ & $\begin{array}{r}-0.22 * \\
(0.10)\end{array}$ & $\begin{array}{c}0.01 \\
(0.15)\end{array}$ & $\begin{array}{c}-0.13 \\
(0.09)\end{array}$ & $\begin{array}{c}0.01 \\
(0.15)\end{array}$ & $\begin{array}{c}-0.14 \\
(0.09)\end{array}$ \\
\hline Female & $\begin{array}{r}-0.09 \\
(0.12)\end{array}$ & $\begin{array}{c}-0.12 \\
(0.08)\end{array}$ & $\begin{array}{r}-0.09 \\
(0.10)\end{array}$ & $\begin{array}{c}-0.11 \\
(0.07)\end{array}$ & $\begin{array}{r}-0.09 \\
(0.10)\end{array}$ & $\begin{array}{c}-0.11 \\
(0.07)\end{array}$ \\
\hline Age $(\log )$ & $\begin{array}{c}0.02 \\
(0.18)\end{array}$ & $\begin{array}{c}0.11 \\
(0.12)\end{array}$ & $\begin{array}{c}0.00 \\
(0.16)\end{array}$ & $\begin{array}{c}0.12 \\
(0.11)\end{array}$ & $\begin{array}{c}0.01 \\
(0.16)\end{array}$ & $\begin{array}{c}0.12 \\
(0.11)\end{array}$ \\
\hline Share of $s$ votes & $\begin{array}{l}1.02 * * * \\
(0.02)\end{array}$ & $\begin{array}{l}1.08 * * * \\
(0.01)\end{array}$ & $\begin{array}{l}1.02 * * * \\
(0.02)\end{array}$ & $\begin{array}{l}1.08 * * * \\
(0.01)\end{array}$ & $\begin{array}{l}1.02 * * * \\
(0.02)\end{array}$ & $\begin{array}{l}1.08 * * * \\
(0.01)\end{array}$ \\
\hline \# of candidates & & & & & $\begin{array}{c}-0.02 \\
(0.02)\end{array}$ & $\begin{array}{l}-0.10^{* * *} \\
(0.01)\end{array}$ \\
\hline Constant & & & & & $\begin{array}{c}0.44 \\
(0.62)\end{array}$ & $\begin{array}{c}0.59 \\
(0.46)\end{array}$ \\
\hline Constituency Fixed Effects & Yes & Yes & & & & \\
\hline Constituency Random Effects & & & Yes & Yes & & \\
\hline $\begin{array}{l}\text { Party fixed effects stratified } \\
\text { by region }\end{array}$ & Yes & Yes & Yes & Yes & Yes & Yes \\
\hline Observations & 2008 & 2514 & 2008 & 2514 & 2008 & 2514 \\
\hline Constituencies & 299 & 299 & 299 & 299 & 299 & 299 \\
\hline
\end{tabular}

Note. Robust standard errors (clustered by constituency) in parentheses. $* p<0.05, * * p<0.01, * * * p<0.001$.

Table A2. DID Estimates of the Effect of the Plagiarism Scandals on the Share of First Votes of Candidates Who Stood at Both Elections in the Same Constituencies

\begin{tabular}{|c|c|c|c|c|}
\hline & DID & DID & DID & DID \\
\hline & $\begin{array}{l}\text { All Repeated } \\
\text { Candidacies }\end{array}$ & $\begin{array}{l}\text { Excl. Top } \\
\text { Politicians }\end{array}$ & $\begin{array}{l}\text { All Repeated } \\
\text { Candidacies }\end{array}$ & $\begin{array}{l}\text { Excl. Top } \\
\text { Politicians }\end{array}$ \\
\hline Dr. & $\begin{array}{r}-0.30 \\
(0.17)\end{array}$ & $\begin{array}{c}-0.22 \\
(0.16)\end{array}$ & & \\
\hline Dr. ${ }^{*} \mathrm{CDU} / \mathrm{CSU} / \mathrm{FDP}$ & & & $\begin{array}{c}-0.55^{*} \\
(0.26)\end{array}$ & $\begin{array}{r}-0.41 \\
(0.24)\end{array}$ \\
\hline Dr.*Other party & & & $\begin{array}{c}-0.01 \\
(0.18)\end{array}$ & $\begin{array}{r}-0.03 \\
(0.19)\end{array}$ \\
\hline Prof. & $\begin{array}{c}0.02 \\
(0.34)\end{array}$ & $\begin{array}{c}-0.11 \\
(0.37)\end{array}$ & $\begin{array}{c}0.00 \\
(0.34)\end{array}$ & $\begin{array}{c}-0.12 \\
(0.38)\end{array}$ \\
\hline Noble title & $\begin{array}{c}-0.25 \\
(0.39)\end{array}$ & $\begin{array}{c}0.07 \\
(0.23)\end{array}$ & $\begin{array}{c}-0.24 \\
(0.37)\end{array}$ & $\begin{array}{c}0.06 \\
(0.24)\end{array}$ \\
\hline Change: MP status & $\begin{array}{l}0.44 * * * \\
(0.12)\end{array}$ & $\begin{array}{l}0.44 * * * \\
(0.11)\end{array}$ & $\begin{array}{l}0.45 * * * \\
(0.12)\end{array}$ & $\begin{array}{l}0.45^{* * * *} \\
(0.12)\end{array}$ \\
\hline Change: District incumbent & $\begin{array}{c}0.25 \\
(0.14)\end{array}$ & $\begin{array}{c}0.24 \\
(0.14)\end{array}$ & $\begin{array}{c}0.25 \\
(0.14)\end{array}$ & $\begin{array}{c}0.24 \\
(0.14)\end{array}$ \\
\hline Change: Top politician & $\begin{array}{c}-0.16 \\
(0.40)\end{array}$ & & $\begin{array}{c}-0.15 \\
(0.39)\end{array}$ & \\
\hline Change: Age (log) & $\begin{array}{c}1.11 \\
(2.03)\end{array}$ & $\begin{array}{c}1.24 \\
(2.05)\end{array}$ & $\begin{array}{c}1.13 \\
(2.02)\end{array}$ & $\begin{array}{l}1.25 \\
(2.04)\end{array}$ \\
\hline
\end{tabular}


Table A2. Continued

\begin{tabular}{|c|c|c|c|c|}
\hline & DID & DID & DID & DID \\
\hline & $\begin{array}{l}\text { All Repeated } \\
\text { Candidacies }\end{array}$ & $\begin{array}{l}\text { Excl. Top } \\
\text { Politicians }\end{array}$ & $\begin{array}{l}\text { All Repeated } \\
\text { Candidacies }\end{array}$ & $\begin{array}{l}\text { Excl. Top } \\
\text { Politicians }\end{array}$ \\
\hline Change: On party list & $\begin{array}{c}0.08 \\
(0.12)\end{array}$ & $\begin{array}{c}0.01 \\
(0.12)\end{array}$ & $\begin{array}{c}0.09 \\
(0.13)\end{array}$ & $\begin{array}{c}0.03 \\
(0.12)\end{array}$ \\
\hline Change: \# of candidates & $\begin{array}{c}-0.18^{* * * *} \\
(0.03)\end{array}$ & $\begin{array}{c}-0.19^{* * * *} \\
(0.03)\end{array}$ & $\begin{array}{c}-0.18^{* * * *} \\
(0.03)\end{array}$ & $\begin{array}{c}-0.19 * * * \\
(0.04)\end{array}$ \\
\hline Change: \# of cand. with Dr. & $\begin{array}{c}-0.12 * \\
(0.06)\end{array}$ & $\begin{array}{c}-0.13^{*} \\
(0.06)\end{array}$ & $\begin{array}{c}-0.12 * \\
(0.06)\end{array}$ & $\begin{array}{c}-0.13^{*} \\
(0.06)\end{array}$ \\
\hline Change: 2nd votes & $\begin{array}{l}0.80 * * * \\
(0.02)\end{array}$ & $\begin{array}{l}0.80 * * * \\
(0.02)\end{array}$ & $\begin{array}{l}0.80 * * * \\
(0.02)\end{array}$ & $\begin{array}{l}0.80 * * * \\
(0.02)\end{array}$ \\
\hline Constant & $\begin{array}{c}-0.31 \\
(0.21)\end{array}$ & $\begin{array}{c}-0.27 \\
(0.21)\end{array}$ & $\begin{array}{c}-0.29 \\
(0.21)\end{array}$ & $\begin{array}{r}-0.27 \\
(0.21)\end{array}$ \\
\hline Party specific trends stratified by region & Yes & Yes & Yes & Yes \\
\hline Observations & 740 & 710 & 740 & 710 \\
\hline
\end{tabular}

Note. Robust standard errors (clustered by constituency) in parentheses. ${ }^{*} p<0.05,{ }^{*} p<0.01, * * * p<0.001$

Table A3. Estimating the Effect of the Doctor's Title on Electoral Success Separately for Candidates From the CDU/ CSU/FDP vs. Those From Other Parties: Linear Fixed Effects, Random Effects, and OLS Regressions of Share of First Votes on Candidate Titles in the 2009 and 2013 Elections

\begin{tabular}{|c|c|c|c|c|c|c|}
\hline & FE & FE & $\mathrm{RE}$ & $\mathrm{RE}$ & OLS & OLS \\
\hline & 2009 & 2013 & 2009 & 2013 & 2009 & 2013 \\
\hline Dr.*CDU/CSU/FDP & $\begin{array}{l}0.69^{* *} \\
(0.25)\end{array}$ & $\begin{array}{c}0.33 \\
(0.18)\end{array}$ & $\begin{array}{c}0.54^{*} \\
(0.22)\end{array}$ & $\begin{array}{c}0.29 \\
(0.17)\end{array}$ & $\begin{array}{c}0.55^{*} \\
(0.22)\end{array}$ & $\begin{array}{c}0.30 \\
(0.17)\end{array}$ \\
\hline Dr.*Other party & $\begin{array}{c}0.50 * \\
(0.22)\end{array}$ & $\begin{array}{c}0.32 * \\
(0.14)\end{array}$ & $\begin{array}{c}0.44 * \\
(0.20)\end{array}$ & $\begin{array}{c}0.24 \\
(0.14)\end{array}$ & $\begin{array}{c}0.45^{*} \\
(0.20)\end{array}$ & $\begin{array}{c}0.24 \\
(0.13)\end{array}$ \\
\hline Prof. & $\begin{array}{l}1.42 * * \\
(0.44)\end{array}$ & $\begin{array}{l}0.95^{* *} \\
(0.30)\end{array}$ & $\begin{array}{l}1.11^{* *} \\
(0.40)\end{array}$ & $\begin{array}{l}0.93 * * * \\
(0.28)\end{array}$ & $\begin{array}{l}1.13^{* *} \\
(0.40)\end{array}$ & $\begin{array}{l}0.95 * * * \\
(0.28)\end{array}$ \\
\hline Noble title & $\begin{array}{c}0.76 \\
(0.74)\end{array}$ & $\begin{array}{c}-0.57 * * \\
(0.21)\end{array}$ & $\begin{array}{c}0.52 \\
(0.67)\end{array}$ & $\begin{array}{c}-0.53^{*} \\
(0.22)\end{array}$ & $\begin{array}{c}0.52 \\
(0.67)\end{array}$ & $\begin{array}{c}-0.52 * \\
(0.21)\end{array}$ \\
\hline Top politician & $\begin{array}{l}3.38 * * * \\
(0.75)\end{array}$ & $\begin{array}{l}1.88 * * \\
(0.71)\end{array}$ & $\begin{array}{l}2.87 * * * \\
(0.66)\end{array}$ & $\begin{array}{l}1.63^{* *} \\
(0.63)\end{array}$ & $\begin{array}{l}2.87 * * * \\
(0.66)\end{array}$ & $\begin{array}{l}1.64 * \\
(0.64)\end{array}$ \\
\hline District incumbent & $\begin{array}{l}3.05 * * * \\
(0.27)\end{array}$ & $\begin{array}{l}1.88 * * * \\
(0.27)\end{array}$ & $\begin{array}{l}2.88^{* * *} \\
(0.26)\end{array}$ & $\begin{array}{l}1.83 * * * \\
(0.26)\end{array}$ & $\begin{array}{l}2.88^{* * * *} \\
(0.26)\end{array}$ & $\begin{array}{l}1.83 * * * \\
(0.26)\end{array}$ \\
\hline MP & $\begin{array}{l}0.92 * * * \\
(0.18)\end{array}$ & $\begin{array}{l}0.86^{* * * *} \\
(0.15)\end{array}$ & $\begin{array}{l}0.74 * * * \\
(0.17)\end{array}$ & $\begin{array}{l}0.70^{* * * *} \\
(0.14)\end{array}$ & $\begin{array}{l}0.74 * * * \\
(0.17)\end{array}$ & $\begin{array}{l}0.71 \text { *** } \\
(0.13)\end{array}$ \\
\hline On party list & $\begin{array}{r}-0.09 \\
(0.10)\end{array}$ & $\begin{array}{r}-0.06 \\
(0.06)\end{array}$ & $\begin{array}{r}-0.13 \\
(0.08)\end{array}$ & $\begin{array}{r}-0.07 \\
(0.05)\end{array}$ & $\begin{array}{r}-0.12 \\
(0.08)\end{array}$ & $\begin{array}{c}-0.03 \\
(0.05)\end{array}$ \\
\hline Other occupation & $\begin{array}{l}0.00 \\
(.)\end{array}$ & $\begin{array}{l}0.00 \\
(.)\end{array}$ & $\begin{array}{l}0.00 \\
(.)\end{array}$ & $\begin{array}{l}0.00 \\
(.)\end{array}$ & $\begin{array}{l}0.00 \\
(.)\end{array}$ & $\begin{array}{l}0.00 \\
(.)\end{array}$ \\
\hline Agriculture & $\begin{array}{c}0.11 \\
(0.46)\end{array}$ & $\begin{array}{c}0.12 \\
(0.26)\end{array}$ & $\begin{array}{c}0.17 \\
(0.36)\end{array}$ & $\begin{array}{c}0.13 \\
(0.25)\end{array}$ & $\begin{array}{c}0.17 \\
(0.36)\end{array}$ & $\begin{array}{c}0.10 \\
(0.24)\end{array}$ \\
\hline Lower manual & $\begin{array}{c}0.08 \\
(0.13)\end{array}$ & $\begin{array}{c}0.02 \\
(0.14)\end{array}$ & $\begin{array}{c}0.10 \\
(0.11)\end{array}$ & $\begin{array}{c}0.05 \\
(0.13)\end{array}$ & $\begin{array}{c}0.10 \\
(0.11)\end{array}$ & $\begin{array}{c}0.04 \\
(0.13)\end{array}$ \\
\hline Higher manual & $\begin{array}{c}0.15 \\
(0.14)\end{array}$ & $\begin{array}{c}0.11 \\
(0.07)\end{array}$ & $\begin{array}{c}0.17 \\
(0.11)\end{array}$ & $\begin{array}{c}0.14^{*} \\
(0.06)\end{array}$ & $\begin{array}{c}0.16 \\
(0.11)\end{array}$ & $\begin{array}{c}0.16^{*} \\
(0.06)\end{array}$ \\
\hline Technical & $\begin{array}{c}-0.26 \\
(0.20)\end{array}$ & $\begin{array}{c}0.08 \\
(0.11)\end{array}$ & $\begin{array}{r}-0.19 \\
(0.17)\end{array}$ & $\begin{array}{c}0.04 \\
(0.11)\end{array}$ & $\begin{array}{r}-0.18 \\
(0.17)\end{array}$ & $\begin{array}{c}0.05 \\
(0.10)\end{array}$ \\
\hline Engineering & $\begin{array}{c}0.21 \\
(0.20)\end{array}$ & $\begin{array}{c}0.11 \\
(0.11)\end{array}$ & $\begin{array}{c}0.24 \\
(0.17)\end{array}$ & $\begin{array}{c}0.12 \\
(0.10)\end{array}$ & $\begin{array}{c}0.24 \\
(0.17)\end{array}$ & $\begin{array}{c}0.12 \\
(0.10)\end{array}$ \\
\hline
\end{tabular}


Table A3. Continued

\begin{tabular}{|c|c|c|c|c|c|c|}
\hline & $\mathrm{FE}$ & FE & $\mathrm{RE}$ & $\mathrm{RE}$ & OLS & OLS \\
\hline & 2009 & 2013 & 2009 & 2013 & 2009 & 2013 \\
\hline Lower service & $\begin{array}{r}-0.03 \\
(0.20)\end{array}$ & $\begin{array}{r}-0.06 \\
(0.12)\end{array}$ & $\begin{array}{c}0.13 \\
(0.36)\end{array}$ & $\begin{array}{r}-0.03 \\
(0.11)\end{array}$ & $\begin{array}{l}0.15 \\
(0.35)\end{array}$ & $\begin{array}{r}-0.04 \\
(0.11)\end{array}$ \\
\hline Higher service & $\begin{array}{c}0.19 \\
(0.15)\end{array}$ & $\begin{array}{c}0.17 \\
(0.12)\end{array}$ & $\begin{array}{c}0.18 \\
(0.14)\end{array}$ & $\begin{array}{c}0.19 \\
(0.10)\end{array}$ & $\begin{array}{c}0.18 \\
(0.14)\end{array}$ & $\begin{array}{c}0.19 \\
(0.10)\end{array}$ \\
\hline Semi-professional & $\begin{array}{c}0.07 \\
(0.14)\end{array}$ & $\begin{array}{c}0.11 \\
(0.09)\end{array}$ & $\begin{array}{c}0.10 \\
(0.13)\end{array}$ & $\begin{array}{c}0.12 \\
(0.09)\end{array}$ & $\begin{array}{c}0.10 \\
(0.13)\end{array}$ & $\begin{array}{c}0.12 \\
(0.09)\end{array}$ \\
\hline Professional & $\begin{array}{c}-0.09 \\
(0.27)\end{array}$ & $\begin{array}{c}0.07 \\
(0.14)\end{array}$ & $\begin{array}{c}0.00 \\
(0.24)\end{array}$ & $\begin{array}{c}0.14 \\
(0.13)\end{array}$ & $\begin{array}{c}0.01 \\
(0.24)\end{array}$ & $\begin{array}{c}0.10 \\
(0.13)\end{array}$ \\
\hline Lo business/admin. & $\begin{array}{c}-0.28 \\
(0.21)\end{array}$ & $\begin{array}{c}-0.01 \\
(0.21)\end{array}$ & $\begin{array}{c}-0.17 \\
(0.17)\end{array}$ & $\begin{array}{c}-0.04 \\
(0.18)\end{array}$ & $\begin{array}{c}-0.16 \\
(0.17)\end{array}$ & $\begin{array}{c}0.02 \\
(0.18)\end{array}$ \\
\hline Hi business/admin. & $\begin{array}{c}0.04 \\
(0.14)\end{array}$ & $\begin{array}{c}0.12 \\
(0.08)\end{array}$ & $\begin{array}{r}-0.02 \\
(0.12)\end{array}$ & $\begin{array}{c}0.12 \\
(0.07)\end{array}$ & $\begin{array}{r}-0.02 \\
(0.12)\end{array}$ & $\begin{array}{c}0.12 \\
(0.07)\end{array}$ \\
\hline Management & $\begin{array}{c}-0.03 \\
(0.18)\end{array}$ & $\begin{array}{c}-0.22 * \\
(0.10)\end{array}$ & $\begin{array}{c}0.01 \\
(0.15)\end{array}$ & $\begin{array}{c}-0.13 \\
(0.09)\end{array}$ & $\begin{array}{c}0.02 \\
(0.15)\end{array}$ & $\begin{array}{c}-0.14 \\
(0.09)\end{array}$ \\
\hline Female & $\begin{array}{c}-0.09 \\
(0.12)\end{array}$ & $\begin{array}{c}-0.12 \\
(0.08)\end{array}$ & $\begin{array}{c}-0.09 \\
(0.10)\end{array}$ & $\begin{array}{c}-0.11 \\
(0.07)\end{array}$ & $\begin{array}{c}-0.09 \\
(0.10)\end{array}$ & $\begin{array}{c}-0.11 \\
(0.07)\end{array}$ \\
\hline Age (log) & $\begin{array}{c}0.02 \\
(0.17)\end{array}$ & $\begin{array}{c}0.11 \\
(0.12)\end{array}$ & $\begin{array}{l}0.01 \\
(0.16)\end{array}$ & $\begin{array}{c}0.13 \\
(0.11)\end{array}$ & $\begin{array}{c}0.01 \\
(0.16)\end{array}$ & $\begin{array}{c}0.12 \\
(0.11)\end{array}$ \\
\hline Share of 2 nd votes & $\begin{array}{l}1.02 * * * \\
(0.02)\end{array}$ & $\begin{array}{l}1.08 * * * \\
(0.01)\end{array}$ & $\begin{array}{l}1.02 * * * \\
(0.02)\end{array}$ & $\begin{array}{l}1.08 * * * \\
(0.01)\end{array}$ & $\begin{array}{l}1.02 * * * \\
(0.02)\end{array}$ & $\begin{array}{l}1.08 * * * \\
(0.01)\end{array}$ \\
\hline \# of candidates & & & & & $\begin{array}{r}-0.02 \\
(0.02)\end{array}$ & $\begin{array}{l}-0.10^{* * * *} \\
(0.01)\end{array}$ \\
\hline Constant & & & & & $\begin{array}{c}0.43 \\
(0.62)\end{array}$ & $\begin{array}{c}0.58 \\
(0.46)\end{array}$ \\
\hline Constituency fixed effects & Yes & Yes & & & & \\
\hline Constituency random effects & & & Yes & Yes & & \\
\hline $\begin{array}{l}\text { Party fixed effects } \\
\text { stratified by region }\end{array}$ & Yes & Yes & Yes & Yes & Yes & Yes \\
\hline Observations & 2008 & 2514 & 2008 & 2514 & 2008 & 2514 \\
\hline Constituencies & 299 & 299 & 299 & 299 & 299 & 299 \\
\hline
\end{tabular}

Note. Robust standard errors (clustered by constituency) in parentheses. ${ }^{*} p<0.05, * * p<0.01, * * * p<0.001$

\section{Supporting Information}

Additional supporting information may be found in the online version of this article at the publisher's website:

Official Lists of Members of the Bundestag and Two State Parliaments Showing MPs Academic Titles

Examples of Campaign Posters Showing the Doctor's Title

Ballot Paper (specimen)

Information on the Plagiarism Scandals

Discussion of Prior Evidence on the Effect of Academic Titles in Germany

Description of Control Variables Used in the Analysis

Table S1: Candidates That Were Coded in the Analysis as Top Politicians Based On Their Prominence in the Previous Legislative Period

Motivating the Use of Statistical Hypothesis Tests

Additional Analyses 
Alternative Tests of Hypothesis 3: Christian Democratic Candidates vs. Other Candidates.

Table S2: Estimating the Effect of the Doctor's Title on Electoral Success Separately For Candidates From the CDU/CSU vs. Those From Other Parties. Linear Fixed Effects, Random Effects, and OLS Regressions of Share of First Votes on Candidate Titles in the 2009 and 2013 Elections.

Table S3: DID Estimates of the Effect of the Plagiarism Scandals on the Share of First Votes of Candidates Who Stood At Both Elections in the Same Constituencies.

Alternative Specification: Not Stratifying Party Fixed Effects By Region.

Table S4: Estimating the Effect of the Doctor's Title on Electoral Success Using Simple Party Fixed Effects (not stratified by region). Linear Fixed Effects, Random Effects, and OLS Regressions of Share of First Votes on Candidate Titles in the 2009 and 2013 Elections.

Table S5: DID Estimates of the Effect of the Plagiarism Scandals on the Share of First Votes of Candidates Who Stood at Both Elections in the Same Constituencies Using Simple Party Fixed Effects (not stratified by region). 